\title{
TADEUSZ STEFAN KURKIEWICZ (1885-1962) - HIS IMPORTANT CONTRIBUTION TO CONTEMPORARY CARDIOLOGY
}

\author{
Ludwik K. Malendowicz $^{1 *}$, Andrzej Łukaszyk ${ }^{1}$
}

\begin{abstract}
Tadeusz Stefan Kurkiewicz (1885-1962) belongs to the well-known Polish histologists and embryologists. His scientific activity started in the Department of Biology and Embryology of the Jagiellonian University in Cracow, which was chaired by professor Emil Godlewski (1875-1944), famous Polish embryologist. Between years 1908-1911, under supervision of the pioneer of the Polish histology, professor Stanisław Maziarski (1873-1959) T. Kurkiewicz continued researches in the Department of Histology of the Jagiellonian University. In 1909 he published results of studies on the development of cardiac muscle in the chick and on the basis of this publication on July 21, 1911 Tadeusz Kurkiewicz received Ph.D. from the Jagiellonian University. Between 1922 and 1959 (with the exception of the period of German occupation) Tadeusz Kurkiewicz was the head of the Department of Histology and Embryology of the Faculty of Medicine of the Poznań University and Academy of Medicine in Poznań (at present: Poznań University of Medical Sciences). His Ph.D. thesis demonstrated that the epicardium originates from pericardial villi, it means from extracardiac source. This great scientific achievement has been confirmed by recent studies. In this article we present curriculum of Tadeusz Kurkiewicz and impact of his discovery on contemporary cardiology.
\end{abstract}

Keywords: heart, embryonic development, epicardium development, Tadeusz Kurkiewicz

\footnotetext{
* Correspondence: lkm@amp.edu.pl

${ }^{1}$ Department of Histology and Embryology, Poznań University of Medical Sciences, Poznań, Poland

Full list of author information is available at the end of article
} 
Professor Tadeusz Stefan Kurkiewicz (18851962) was the well-known Polish histologist and embryologist, and head of the Department of Histology and Embryology of the present Poznan University of Medical Sciences (Fig. 1). In a tribute to his memory we present an outline of his curriculum. Moreover, we overview the impact of T. Kurkiewicz's studies on developing heart on contemporary cardiology, especially in the field of searches for cardiac stem cells.

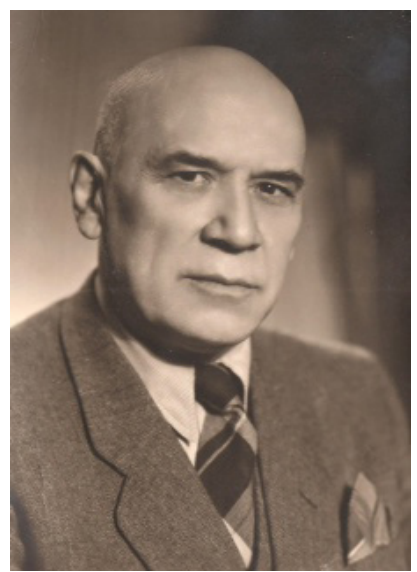

Figure 1 Tadeusz Stefan Kurkiewicz (photo taken ca 1955, from the archives of the Department of Histology and Embryology, Poznań University of Medical Sciences)

Tadeusz Stefan Kurkiewicz was born on February 23,1885 , in the village of Strzegowo near Mława (the Russian zone following partition of Poland) to Franciszek, a teacher and Zofia, maiden name Krusiewicz.

In 1902 he received the general certificate of education from the classic school at Płock and started to study natural sciences at the Faculty of Physics and Mathematics of the Imperial University of Warsaw (present Warsaw University). From 1906 he continued studies at the Faculty of Philosophy, Jagiellonian University at Cracow. During studies he worked in the Department of Biology and Embryology which was chaired by professor Emil Godlewski (1875-1944), famous Polish embryologist. Between years 1908-1911, under supervision of the pioneer of the Polish histology, professor Stanisław Maziarski (1873-1959) T. Kurkiewicz continued researches in the Department of Histology of the Jagiellonian University. In 1909 he published results of studies on the development of cardiac muscle in the chick [1] and on the basis of this publication on July 21, 1911 Tadeusz Kurkiewicz received Ph.D. from the Jagiellonian University (Figs. 2, 3). Of importance is that the title of dissertation is in Polish and German while the entire text only in German.

In the same year he returned to Warsaw and worked in the Laboratory of Histology of the Imperial University of Warsaw, which was chaired by professor A. Kołosow. In 1914 Kurkiewicz published observations on Paneth cells in mammals [2].
BULLETIN INTERNATIONAL

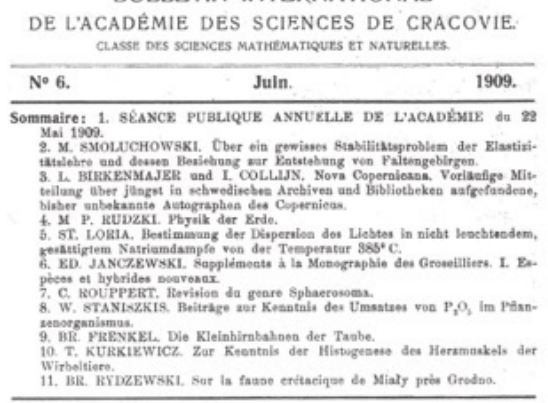

Figure 2 Program of the meeting of the Academy of Science of Cracow, No 6, June 1909

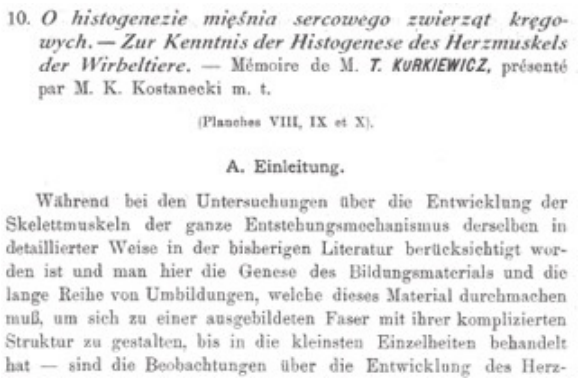

Figure 3 Title and the beginning of the T. Kurkiewicz's publication

Following outbreak of the World War I, T. Kurkiewicz was evacuated to Tomsk (Russia), where he worked as a prosector in the Department of Histology of the Imperial Tomsk University (chairman: professor S.G. Tchasownikow / С.Г. Часовников). There, in 1921, on the basis of studies on passage of striated muscles into tendon T. Kurkiewicz obtained Doctor of Sciences degree (habilitation). In 1922 he returned to independent Poland and settled in Poznań. In the same year he accepted duties of the chairman of the Department of Normal Histology and Embryology of the Poznań University. In 1922 T. Kurkiewicz accomplished a Polish habilitation (with the same thesis) and was appointed a chairman of the above mentioned Department. He remained at post there till his retirement in 1959 (with break during the World War II).

During the interwar years Tadeusz Kurkiewicz worked for a few months (1927) in Zoological Station in Naples (Italy) where he collected a rich research material on the earliest stages of development of Echinoidea and Tunicata, with special emphasis on cleavage and blastomere formation. On basis of this material, between years 1929-1931 T. Kurkiewicz published few articles concerning mechanisms of the cleavage [3]. He also performed important studies on mechanism of adrenaline release from chromaffin cells of the adrenal medulla [4]. In Polish literature his method of adrenaline cell visualization is named the reaction of Henle-Kurkiewicz. 
In these times professor T. Kurkiewicz served as a vice-dean and in years 1935-1937 the dean of the Faculty of Medicine of the Poznań University.

During the World War II he moved to Warsaw. Officially Tadeusz Kurkiewicz was employed in hospital division of the city council and in the Red Cross Hospital. In conspiracy he served as a lecturing professor of histology and embryology at the underground University of the Western Lands (Polish: Uniwersytet Ziem Zachodnich) and also underground Warsaw University.

Professor Tadeusz Kurkiewicz returned to Poznań in March 1945 and resumed the chairmanship of the Department of Histology and Embryology. In the postwar period he focused activity on teaching and administrative works. He also organized modern laboratories, in which numerous prominent Polish scientists completed their Ph.D. and habilitation theses. Among them were Tadeusz Pawlikowski, Jan Kanty Słotwiński, Kazimierz Miętkiewski and Kazimierz Dux. In 1947 he published the excellent textbook „Outline of human histology. Part 1 (Cell and tissues)” [5].

In years 1945-46 and 1947-1948 professor Kurkiewicz again served as a dean of the Faculty of Medicine. With foundation of the Medical Academy (present Poznań University of Medical Sciences) Tadeusz Kurkiewicz received nomination for rector (president), and served at this post till 1952.

Professor Tadeusz Kurkiewicz died in Poznań on March 11, 1962.

An extensive curriculum of Tadeusz Kurkiewicz has been published in Polish [6, 7].

The greatest scientific achievement of Tadeusz Kurkiewicz was connected with his studies in Cracow, where he naturally came under the influence of professor Emil Godlewski, and this influence fostered in Kurkiewicz a passion for embryology. His original observations were performed on the development of heart in chicken and revealed new facts about origin of epicardial cells [1]. At days 2 and 3 of egg incubation a material for histologic studies was collected every 3 h, while between days 4-7 every 6 h. Moreover, developmental stages of studied embryos were also checked by myomere counts. Technical skills and detailed, systematic and time-consuming studies allowed T. Kurkiewicz to trace the origin of the epicardial cells in the developing heart. In contrast to the earlier hypotheses claiming that both myocardium and epicardium originate from the same source of the primitive heart tube - myoepicardium or epimyocardium, Kurkiewicz demonstrated that the epicardium originates from pericardial villi, it means from extracardiac source. As known, mesoderm-derived pericardial villi cover the ventral wall of the sinus venosus. An excellent review of this work and its impact on contemporary cardiology was published by Männer et al. in 2001 [8].
Although in publications of "Carnegie Institution of Washington" (1918) the paper of T. Kurkiewicz is mentioned and its cytological aspects extracted [9], it seems that for over 50 years his observations on developing heart remained unknown to other embryologists. Männer et al. [8] supposed that "The discovery of Kurkiewicz's [1909] paper in the late 1960s seems to be the merit of Romanoff's [1960] profound knowledge of the literature on embryonic development of the chick". Indeed, Romanoff's book contains numerous details on heart development which were described by Kurkiewicz [10]. However, it seems that it was Manasek $[11,12]$ who attracted embryologists to the original paper born in Cracow. His light and electron microscopic studies revealed cardiac stem
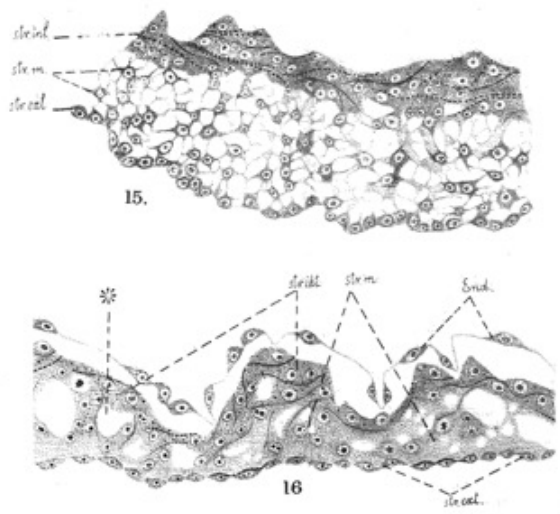

Figure 4 Original drawings illustrating chicken heart at day 3 of development demonstrated by T. Kurkiewicz (in his publication figs 15 and 16)

that by stage 12 (15 somites) of chick development the heart wall was composed only of cells that contained myofibrils, and no epicardial cells were present. Manasek accentuated that his findings supported original Kurkiewicz's [1] observations. Of interest is that some microphotographs taken by Manasek are very similar to drawings performed by T. Kurkiewicz (Fig. 4). In subsequent years the idea of extracardiac origin of epicardial cells became commonly accepted.

Why the discovery of Kurkiewicz's paper is so important for modern cardiology? Growing body of evidence from recent publications suggests that epicardium derived cells differentiate into components of coronary vessels (coronary endothelial and smooth muscle cells) as well as components of the fibrous skeleton of the heart and cushion mesenchyme. As demonstrated by modern molecular biology techniques, these cells play regulatory role in cardiac development (signaling centers governing the development) as well as in Purkinje cell differentiation. They also regulate adult cardiomyocyte phenotype and function. It is believed that as a multipotential cells, epicardium derived cells are 
cells. And in fact, promising results of experiments with epicardium derived cells grafting into ischemic or infarcted myocardium have been reported [13, $14,15]$.

In attached references we included papers which, to our knowledge, contain citation of T. Kurkiewicz's doctoral dissertation $[8,53]$. Original observations of professor Kurkiewicz are also cited in various textbooks and handbooks [for example 9-10, 21, 54-61] or dissertations non listed in SCI [62-67]. Furthermore, name of $\mathrm{T}$. Kurkiewicz appears in numerous original publications, although his fundamental publication is not included into the references (for example "theory challenged as early as 1909 by Kurkiewicz" [68], "in 1909 Kurkiewicz identified the pro-epicardium as the source of the epicardium" [69].

\section{Competing interests}

The authors declare they have no conflict of interest

\section{Author details}

Ludwik K. Malendowicz, Department of Histology and Embryology, Poznań University of Medical Sciences, 6 Święcicki St., 60-781 Poznań, Poland. Phone: +(48)61.854.6444; fax: +(48)61.854.6440; mail:1km@amp.edu.pl

Received: 28 August 2017

Accepted: 08 September 2017

\section{References}

1. Kurkiewicz T. O histogenezie mięśnia sercowego zwierząt kręgowych. Zur Kenntnis des Histogenese des Herzmuskels der Wirbeltiere. Bull Int Acad Sci Cracovie. 1909;148-191.

2. Kurkiewicz T. On Paneth cells in mammals. (Russian) Warsaw, Warsaw Regional Scientific Printing 1914;1-10.

3. Kurkiewicz T. Sur la fonction glycogénique du noyau cellulaire au cours du développement des oeufs d'oursins. C R Ass Anat. 1931;26:343-351.

4. Kurkiewicz T. Sur la partipation du noyau cellulaire a la production d'adrénaline. C R Ass Anat. 1931;26:352-355

5. Kurkiewicz T. Histologia człowieka w zarysie. Cz. 1, (Nauka o komórce i tkankach) [Outline of human histology. Part 1 (Cellandtissues)]. Poznań University Printing 1947;1-228.

6. Łukaszyk A. Tadeusz Stefan Kurkiewicz (1885-1962). Histolog. (Polish). In: Hasik J, Meissner RK eds: Outlines to portraits of representatives of Poznań medicine 1945-1985. Poznań, 1991;213-215.

7. Łukaszyk A. Tadeusz Stefan Kurkiewicz (1885-1962) (Polish). In: Meissner RK ed.: Book of remembrance in 80 anniversary of the University Faculty of Medicine in Poznań. Medical Academy Printing, Poznań 2001;87-91.

8. Männer J, Pérez-Pomares JM, Macías D, Muñoz-Chápuli R. The origin formation and developmental significance of the epicardium: A review. Cells Tissues Organs 2001;169:89-103. DOI: 10.1159/000047867

9. Cowdry EV. The mitochondrial constituents of protoplasm. In: Contributions to Embryology 1918; Vol. VIII, Nos. 24, 25, 26, Published by the Carnegie Institution of Washington, (Publication No. 271) Washington (1918)

10. Romanoff AL. The Avian Embryo. Structural and Functional Development. New York, Macmillian (1960)

11. Manasek FJ. Embryonic development of the heart. I. A light and electron microscopic study of myocardial development in the early chick embryo. J Morphol. 1968;125:329-365. DOI: 10.1002/jmor.1051250306

12. Manasek FJ. Embryonic development of the heart. II. Formation of the epicardium. J Embryol Exp Morphol. 1969;22:333-348.

13. Virágh S. Challice CE. Origin and differentiation of cardiac muscle cells in the mouse. I Ultrasruct Res. 1973;42:1-24. DOI: 10.1016/ S0022-5320(73)80002-4

14. Viragh S. Challice CE. The origin of the epicardium and the embryonic myocardial circulation in the mouse. Anatomical Rec. 1981;201:157168. DOI: $10.1002 /$ ar.1092010117

15. Beltrami AP, Barlucchi L, Torella D, Baker M, Limana F, Chimenti S, Kasahara H, Rota M, Musso E, Urbanek K, Leri A, et al. Adult cardiac stem cells are multipotent and support myocardial regeneration. Cell 2003;114:763-776.

16. Shiozaki M. Shimada Y. Intercellular junctions in embryonic chick cardiac muscle revealed by rapid freezing and freeze-substitution. Microscopy Res Tech. 1992;20:305-313. DOI: 10.1002/jemt.1070200311

17. Urbanek K, Rota M, Cascapera S, Bearzi C , Nascim-bene A, De Angelis A, Hosoda T, Chimenti S, Baker M, Limana F, Nurzynska D, et al. Cardiac stem cells possess growth factor-receptor systems that after activation regenerate the infarcted myocardium, improving ventricular function and long-term survival. Circ Res. 2005;97:663-673. DOI: 10.1161/01. RES.0000183733.53101.11

18. Winter EM, Gittenberger-de Groot AC. Cardiovascular development: towards biomedical applicability. Epicardium-derived cells in cardiogenesis and cardiac regeneration. Cell Mol Life Scien. 2007;64:692-703. DOI: 10.1007/s00018-007-6522-3

19. Ho E, Shimada Y. Formation of the epicardium studied with the scanning electron microscope. Develop Biol. 1978;66:579-585. DOI: 10.1016/0012-1606(78)90263-4

20. Shimada Y, Ho E, Toyota N. Epicardial covering over myocardial wall in the chicken embryo as seen with the scanning electron microscope. Scan Electron Microsc. 1981;2:275-280.

21. Canale ED, Campbel, GR, Smolich JJ, Campbell JH. Cardiac Muscle. In: Oksche A, Vollrath L. Handbook of Microscopic Anatomy. New York 1986;8-51.

22. Komiyama M, Ito K, Shimada Y. Origin and development of the epicardium in the mouse embryo. Anat Embryol. 1987;176:183-189. DOI: 10.1007/BF00310051

23. Icardo JM, Fernandez-Terán A. Morphologic study of ventricular trabec ulation in the embryonic chick heart. Acta Anatom. 1987;130:264-274.

24. Kuhn HJ, Liebherr G. The early development of the epicardium in Tupaia belangeri. Anat Embryol. 1988;177:225-234. DOI: 10.1007/ BF00321133

25. Hiruma T, Hirakow R. Epicardial formation in embryonic chick heart Computer-aided reconstruction, scanning, and transmission electron microscopic studies. Am J Anat. 1989;184:129-138. DOI: 10.1002/ aja.1001840204

26. Virágh S, Kálmán F, Gittenberger-de Groot AC, Poelmann RE, Moorman AFM. Angiogenesis and hematopoiesis in the epicardium of the vertebrate embryo heart. Ann NY Acad Scien. 1990;588:455-458. DOI 10.1111/j.1749-6632.1990.tb13262.x

27. Männer J. The development of pericardial villi in the chick embryo. Anat Embryol. 1992;186:379-385.

28. Männer J. Experimental study on the formation of the epicardium in chick embryos. Anat Embryol. 1993;187:281-289.

29. Virágh S, Gittenberger-de Groot AC, Poelmann RE, Kálmán F. Early development of quail heart epicardium and associated vascular and glandular structures. Anat Embryol. 1993;188:381-393. DOI: 10.1007/ BF00185947

30. Vrancken Peeters MPFM, Mentink MMT, Poelmann RE, Gittenberger-de Groot AC. Cytokeratins as a marker for epicardial formation in the quail embryo. Anat Embryol. 1995;191:503-508. DOI: 10.1007/BF00186740

31. van den Eijnde SM, Wenink ACG, Vermeij-Keers C. Origin of subepicardial cells in rat embryos. Anat Rec. 1995;242:96-102. DOI: 10.1002/ ar.1092420113

32. Kálmán F, Virágh S, Módis L. Cell surface glycoconjugates and the extracellular matrix of the developing mouse embryo epicardium. Anat Embryol. 1995;191:451-464. DOI: 10.1007/BF00304430

33. Muñoz-Chápuli R, Macías D, González-Iriarte M, Carmona R, Atencia G Pérez-Pomares HM. El epicardio y las células derivadas del epicardio: múltiples funciones en el desarrollo cardíaco (The epicardium and epicardial-derived cells: Multiple functions in cardiac development). Rev Esp Cardiol. 2002;55:1070-1082. PubMed ID: 12383393

34. Ai J-P, Li Y.-Q, Wu X-S. The Origin and Development of the Epicardium (Chinese). Life Science Research , 2002;6( Suppl):75-78.

35. Majesky MW. Development of coronary vessels. Curr Topics Develop Biol. 2004;62:225-259. DOI: 10.1016/S0070-2153(04)62008-4

36. Wessels A, Pérez-Pomares J. The epicardium and epicardially derived cells (EPDCs) as cardiac stem cells. Anat Rec. 2004;276A:43-57. PubMed ID: 14699633 DOI: 10.1002/ar.a.10129

37. Ratajska A, Czarnowska E, Kołodzińska A, Kluzek W, Leśniak W. Vasculogenesis of the embryonic heart: Origin of blood island-like structures. Anat Rec. 2006;288A:223-232. DOI: 10.1002/ar.a.20311

38. Männer J, Ruiz-Lozano P. Development and function of the epicardium. Adv Develop Biol. 2007;18:333-357. DOI: 10.1016/ S1574-3349(07)18013-3

39. Schulte I, Schlueter J, Abu-Issa R, Brand T, Männer J. Morphological and molecular left-right asymmetries in the development of the proepicar- 
dium: A comparative analysis on mouse and chick embryos. Dev Dyn 2007;236:684-695. DOI: 10.1002/dvdy.21065

40. Green J. Crossland R. Langford JK. Epicardial formation in situ and in culture. Texas J. Microscopy 2007;38:100-106.

41. Ratajska A. Czarnowska E. Vasculogenesis of the embryonic heart: Contribution of nucleated red blood cells to early vascular structures. Cardiovascular and Hematological Disorders - Drug Targets. 2006;6:219225. DOI: $10.2174 / 187152906778249527$

42. Jahr M, Schlueter J, Brand T, Männer J. Development of the proepicardium in Xenopus laevis. Dev Dyn. 2008;237:3088-3096. DOI: 10.1002/ dvdy. 21713

43. Ratajska A, Czarnowska E, Ciszek B. Embryonic development of the proepicardium and coronary vessels. Int J Dev Biol. 2008;52:229-236. DOI: $10.1387 / \mathrm{ijdb} .072340 \mathrm{ar}$

44. Потоцька ОЮ. Походження епікардутайого структурнофункціональний внесок у формування гетерогенності серця (Origin of epicardium, it's structural and functional role in heart heterogeneity formation). Морфологія 2008;2:6-15.

45. Потоцкая ОЮ. (2008). Новый источник эпикарда у птиц: морфологическое наблюдение (A novel source of epicardium in birds: morphological observation). Морфологія 2008;2:37-43.

46. González Rosa JM, Padrón Barthe L, Torres M, Mercader N. Estudios de linaje del epicardio durante el desarrollo y la regeneración cardiaca. Rev española cardiol. 2010;63:36-48. DOI: 10.1016/ S0300-8932(10)70151-2

47. Riley PR. An epicardial floor plan for building and rebuilding the mammalian heart. Curr Topics Develop Biol. 2012;100:234-252. DOI: 10.1016/B978-0-12-387786-4.00007-5

48. Muñoz-Chápuli R. Epicardial development. Eur J Anat. 2011;15:10-16.

49. Cano E, Carmona R, Muñoz-Chápuli R. Evolutionary Origin of the Proepicardium. J Dev Biol. 2013;1:3-19. DOI: 10.1111/ede.12130

50. Männer J. Microsurgical Procedures for Studying the Developmental Significance of the Proepicardium and Epicardium in Avian Embryos: PE-Blocking, PE-Photoablation, and PE-Grafting. J Dev Biol. 2013;1:47-63.

51. Dangel J. Changing physiology in the first-to third-trimester foetal circulation. Cardiology in the Young 2014;24(S2):13-18 doi: 10.1017/ S1047951114001395

52. Masters M. Riley PR. The epicardium signals the way towards heart regeneration. Stem cell res. 2014;13:683-692. DOI: $10.1016 / \mathrm{j}$ scr.2014.04.007

53. Королев ВА. Потоцкая ОЮ. ПРЕХОРДАЛЬНАЯ И МИОЭПИКАРДИАЛЬНАЯ ПЛАСТИНКИ: ТЕРМИНОЛОГИЧЕСКИЕ ACПЕКТЫ, ПРОБЛЕМЫ ОПРЕДЕЛЕНИЯ (PRECHORDAL AND MYOEPICARDIAL PLATES: TERMINOLOGICAL ASPECTS, THE PROBLEMS OF DEFINITION). Морфология 2015;148:62-69.

54. Wassermann F. BeschreibenderTeil. In: Die Lebendige Masse. Springer Berlin Heidelberg 1929;590-716.

55. Benninghoff A. Blutgefaße und Herz. In: Handbuch der mikroskopischen Anatomie des Menschen. Möllendorff V. W. ed. Sechster Band, Erster Teil, Springer-Verlag Berlin Heidelberg GmbH 1930;1-584.

56. Häggqvist G. Herzmuskelgewebe. In: Die Gewebe. Springer Verlag (1956).

57. Steding G, Seidl W, Christ B. Cardio-vaskuläres System. In: Humanembryologie, Springer Berlin Heidelberg 1990;205-294.

58. Rumyantsev PP. Growth and hyperplasia of cardiac muscle cells (Vol. 3 ) Taylor \& Francis (1991) 1-70 ISBN:3718649586, 9783718649587

59. Kirby ML. Cardiac Development. Oxford and New York, NY: Oxford University Press (2007)

60. Tomanek RJ. (2012). Coronary vasculature: Development, structure-function, and adaptations. Springer Science \& Business Media (2012) DOI 10.1007/978-1-4614-4887-7 (2012)

61. Tomanek RJ. Prenatal Coronary Morphogenesis. In: Coronary Vasculature: Development, Structure-Function, and Adaptation, Springer Science+Business Media, New York 2013;25-46. DOI 10.1007/978-1-4614-4887-7

62. Schulte I. Induktion und Differenzierung der proepikardialen Serosa: Analyse einer Vorläuferzellpopulation des embryonalen Herzens. Dissertation zur Erlangung des Doktorgrades der Mathematisch-Naturwissenschaftlichen Fakultäten der Georg-August-Universität zu Göttingen, Göttingen 2007;1-101

63. Green JE. Epicardial formation: In situ and in vitro SEM comparison study. Stephen F. Austin State University, ProQuest Dissertations Publishing 2007. 1449498 (2007).

64. Winter EM. From cardiogenesis to cardiac regeneration: focus on epicardium-derived cells. Doctoral thesis. Department of Anatomy and Embryology, Faculty of Medicine, Leiden University Medical Center (LUMC) Leiden 2009;1-216.
65. Jahr M. Lageentwicklung des Proepikards und des Mündungsabschnittes des Pulmonalvenenstammes bei Xenopus laevis. Inaugural - Dissertation zur Erlangung des Doktorgrades der Medizinischen Fakultät der Georg-August-Universität zu Göttingen, Göttingen 2009;1-56.

66. Salgado Somoza A. Estudio proteómico diferencial en tejido adiposo epicárdico y subcutáneo de pacientes con cardiopatía isquémica. Tesis Doctoral, Universidad de Santiago de Compostela, Facultad de Medicina y Odontología, Departamento de Medicina 2011;1-185 http://hdl.handle.net/10347/3614

67. Boulberdaa M. Rôle de la voie de signalisation du récepteur-1 des prokinéticinesdans la function cardiaque et rénale: implication des cellules progénitrices (Doctoral dissertation, Strasbourg) 2012;1-280.

68. Sylva M. van den Hoff MJB. Moorman AFM. Development of the Human Heart. Am J Med Genet. Part A (2013) 1-25. DOI: 10.1002/ajmg.a.35896

69. Lluri G., Aboulhosn J. Coronary Arterial Development: A Review of Normal and Congenitally Anomalous Patterns. Clin Cardiol. DOI:10.1002/ clc.22237 (2014) 